\title{
Neurobehavioral and neuroprotector effects of caffeine in animal models
}

\author{
Dina Villanueva-García - Daniel Mota-Rojas (iD - Agatha Miranda-Cortés - Patricia Mora-Medina (iD). \\ Ismael Hernández-Avalos iD. Alejandro Casas-Alvarado • Adriana Olmos-Hernández iD . Julio Martínez-Burnes iD
}

\section{Villanueva-García}

Division of Neonatology, National Institute of Health Hospital Infantil de México Federico Gómez, Mexico City, Mexico.

D Mota-Rojas (Corresponding author) - A Casas-Alvarado Neurophysiology, Behavior, and Animal Welfare Assessment, Department of Animal Production and Agriculture (DPAA), Universidad Autónoma Metropolitana (UAM) Xochimilco Campus, 04960, Mexico City, Mexico.

email:dmota@correo.xoc.uam.mx

\section{A Miranda-Cortés - I Hernández-Avalos}

Clinical Pharmacology and Veterinary Anaesthesia. Department of Biological Science. Universidad Nacional Autónoma de México (UNAM), FESC, 54714, Mexico.

\section{P Mora-Medina}

Livestock Science Department, Universidad Nacional Autónoma de México (UNAM), Facultad de Estudios Superiores Cuautitlán, 54714, State of Mexico, Mexico.

\section{A Olmos-Hernández}

Bioterio y Cirugía Experimental, National Rehabilitation Institute "Luis Guillermo Ibarra Ibarra" (INRLGII), Secretaría de Salud (SSA), Mexico City, Mexico.

\section{J Martínez-Burnes}

Graduate and Research Department, Facultad de Medicina Veterinaria y Zootecnia, Universidad Autónoma de Tamaulipas, Victoria City, Tamaulipas, Mexico.

Received: June 29, 2020 • Accepted: July 17, 2020 • Published Online: August 16, 2020

\begin{abstract}
This review aims to analyze and contrast the neurological effects associated with the use of caffeine on neurobehavior and neuroprotection in animal models. Caffeine belongs to the group of methylxanthines that exert a direct effect on adenosine receptors associated with inhibitory or excitatory $\mathrm{G}$ proteins, generating modification of cyclic AMP activity and intracellular calcium flow which produces alterations in the modulation system of the neurotransmitters dopamine and glutamate. The regulation of the neurotransmission systems generates protection against the inflammation of the central nervous system, by activation of the microglia and reinforcement of the blood-brain barrier. This drug will also restore cognition or prevent memory loss in Parkinson's or Alzheimer's diseases. It is important to establish new study models in other species to assess whether the behavior of the molecule is similar and to obtain other clinical applications in its behavioral and neuroprotective effects.
\end{abstract}

Keywords: adenosine receptor, caffeine consumption, cognition, dose, hypothalamus, neurodegenerative diseases, pharmacodynamic

\section{Introduction}

Caffeine (1,3,7-trimethylxanthine) is the most widelyused psychoactive drug worldwide. It is a non-specific adenosine receptor (RA) antagonist that bonds to three RA (A1, A2a, A2b) with a preference, under normal physiological conditions, for the $\mathrm{A} 1$ and $\mathrm{A} 2 \mathrm{a}$ receptors (Fredholm et al 2011). In the brain, these receptors are expressed, respectively, in the pre- and post-synaptic sites of neurons, though they are also present in astrocytes, oligodendrocytes, and microglia (Sheth et al 2014). The A2a receptor is involved in neuroinflammation, and its expression in microglial cells increases after a cerebral lesion (Ohta et al 2001).

A member of the methylxanthine group of molecules, caffeine exerts a stimulating effect on the central nervous system (CNS) (Fredholm et al 1999; Fredholm et al 2005; Villanueva-García 2011; Villanueva-García and Ibarra 2016). Caffeine readily crosses cell membranes, so when ingested it quickly reaches the CNS where it modifies cell processes, stimulates intellectual activity, inhibits sleep, or reduces fatigue (Fredholm et al 1999; Góngora et al 2005). Its mechanism can participate in neurobehavioral alterations by generating increased muscular activity and modulating cognition and anxiety (Hughes, 2016; Abu-Sa'da et al 2018; Alasmari, 2020). In the first two cases, therapeutic use benefits activities that entail intense physical performance or mental complexity (Southward et al 2018). Caffeine's anxiogenic effect is also important because it increases alertness by stimulating key regions involved in states of panic (Price, 2005). Moreover, it has neuroprotector and cytoprotector 
effects in cases of dopamine-induced damage by regulating the levels of this neurotransmitter (Kalda et al 2006). Caffeine has also been associated with an effect that retards signs of neuronal degeneration in diseases like Parkinson's and Alzheimer's; effects that occur through interaction with adenosine receptors and a possible association with N-methylD-aspartate receptors (NMDA), which increase cognition and delay the onset of the associated signs (Diler et al 2013; Kim et al 2018).

The objective of this review is to analyze and contrast the neurological effects associated with the neurobehavioral and neuroprotector effects of the use of caffeine, in addition to discussing the potential scope of its use in animal models.

\section{Pharmacodynamic effects of caffeine}

Caffeine's main action mechanism is the antagonism of the A1, A2, and A3 adenosine receptors present in different areas of the CNS, including the nucleus accumbens, striatum, hypothalamus, cerebral cortex, hippocampus, olfactory bulb and tubercle (Salamone and Correa, 2012; Simoes et al 2016). This antagonism participates in inhibiting or exciting the $G$ protein $(\mathrm{pG})$ by altering phosphorylation of cyclic AMP and, as a result, modifying the flow of intracellular calcium (Kolahdouzan and Hamadeh, 2016) and the systems that modulate dopamine and glutamate release (Solinas et al 2002; Villanueva-García 2007; Villegas and Villanueva-García 2016; Lopes et al 2019; Alasmari et al 2020). The physiological effects of caffeine depend on the density of the receptors and the region of the CNS where they are found (Figure 1).

Antagonism of the A1 and A3 receptors activates inhibitory $\mathrm{pG}$. This is followed by inhibition of adenylate cyclase, which reduces the conversion of adenosine monophosphate (AMP) to cyclic AMP, thus decreasing activation of the kinase A protein. If this molecule is not in an activated state, then phosphorylation of the calcium channels is not generated, resulting in conditions that impede the influx of this ion to the intracellular level (Kolahdouzan and Hamadeh, 2016). A2 receptors, in contrast, are associated with pG stimulators that produce an increase of adenylate cyclase and cyclic AMP that augments the sensitivity of the calcium channels, allowing this cation to enter the cell (Kamp and Hell, 2000; Dias et al 2013) (Figure 3). The modulation of adenosine A receptors and the reduction of the activity of the adenosine kinase enzyme (Fredholm et al 1999) are responsible for generating the modulation of receptors in various pathways, as shown in Figure 2.

It has been suggested that dopamine may perform a kind of competitive action with caffeine through D2 and A2 adenosine receptors (Ferré et al 1991). In this way, the antagonism of the A2 receptors would explain the potentializing of the vasomotor effects, together with the increase of dopamine in the nucleus accumbens (El Yacoumbi et al 2000).

Volkow et al (2015) found that caffeine induced an increased affinity to receptors in the ventral striatum that explains changes in thermoregulation and metabolism in the human brain. Zheng and Hasegawa (2016) corroborated this by administering caffeine intraperitoneally to Wistar rats and observing decreases in temperature and oxygen consumption that they attributed to dopamine release.

The antagonism of A1 adenosine receptors also generates glutamate exocytosis (Kerkhofs et al 2017). Studies with rats have found a correlation between the density of A1 receptors and increased glutamate concentrations in the nucleus accumbens and posterior hypothalamus (Solinas et al 2002; John et al 2014). Although the precise mechanism that produces this exocytosis remains unknown, the theory proposed in this regard is related to the glutamate cotransporter 1 in the nucleus accumbens, which can modulate the capture of aspartate and glutamate in the A2 receptor (Das et al 2015; De Freitas et al 2016).

\section{Neurobehavioral effect}

Caffeine can generate neurobehavioral effects that include increased activity, anxiety (state of alertness), and cognition (Hughes, 2016; Abu-Sa'da et al 2018; Alasmari, 2020). These effects are closely related to the chronic consumption of this substance (Spaeth et al 2014).

\section{Caffeine and increased activity}

Caffeine has ergogenic effects that increase muscular power (Garret and Holtzman, 1994; Fisone et al 2004; Halldner et al 2004). In human medicine, a dose of 3-13 mg kg-1 has been shown to improve physical performance in sporting activities (Sökmen et al 2008), while meta-analyses have found that moderate consumption produces significant ergogenic aid in athletic performance (Ganio et al 2009; Southward et al 2018). Volkow et al (2015), in turn, pointed out that caffeine not only generates an increase of extracellular dopamine but also increases affinity to the D2 and D3 receptors in the ventral striatum by fostering changes in thermoregulation and metabolism in the brain. This theory sustains that a competitive action which is dose-dependent may exist between the D2 dopamine and A2 adenosine receptors (Ferré et al 1991) because caffeine antagonizes the latter, thus potentializing vasomotor effects by inducing an increase of dopamine in the nucleus accumbens (El Yacoumbi et al 2000).

In other research, Marin et al (2011) observed a biphasic effect of caffeine in adolescent (37-40 days) and adult (70-74 days) Wistar rats in two experiments. In the first procedure, the rats were exposed to an environment where they were habituated to caffeine via intraperitoneal 
administration at doses of $3,10,30,60$, or $120 \mathrm{mg} \mathrm{kg}-1$. In the second, the rats received caffeine at doses of 30,60 , or $120 \mathrm{mg}$ kg-1. The authors concluded that a biphasic effect occurred characterized by stimulation of locomotion at low-tomoderate doses, but no effect, or depression of locomotion, at high doses. Greater stimulation was observed in the adolescent rats compared to the adults, while depressed locomotion was seen only in the non-habituated adults.
The dominant effect of caffeine on muscular activity is due to dopamine's action on neuronal excitation. It is not yet possible, however, to ascertain whether this effect occurs through an increase of extracellular dopamine or an increased affinity of this neurotransmitter to its receptors. The biphasic response mentioned above means we must consider both the dose and age of individuals.

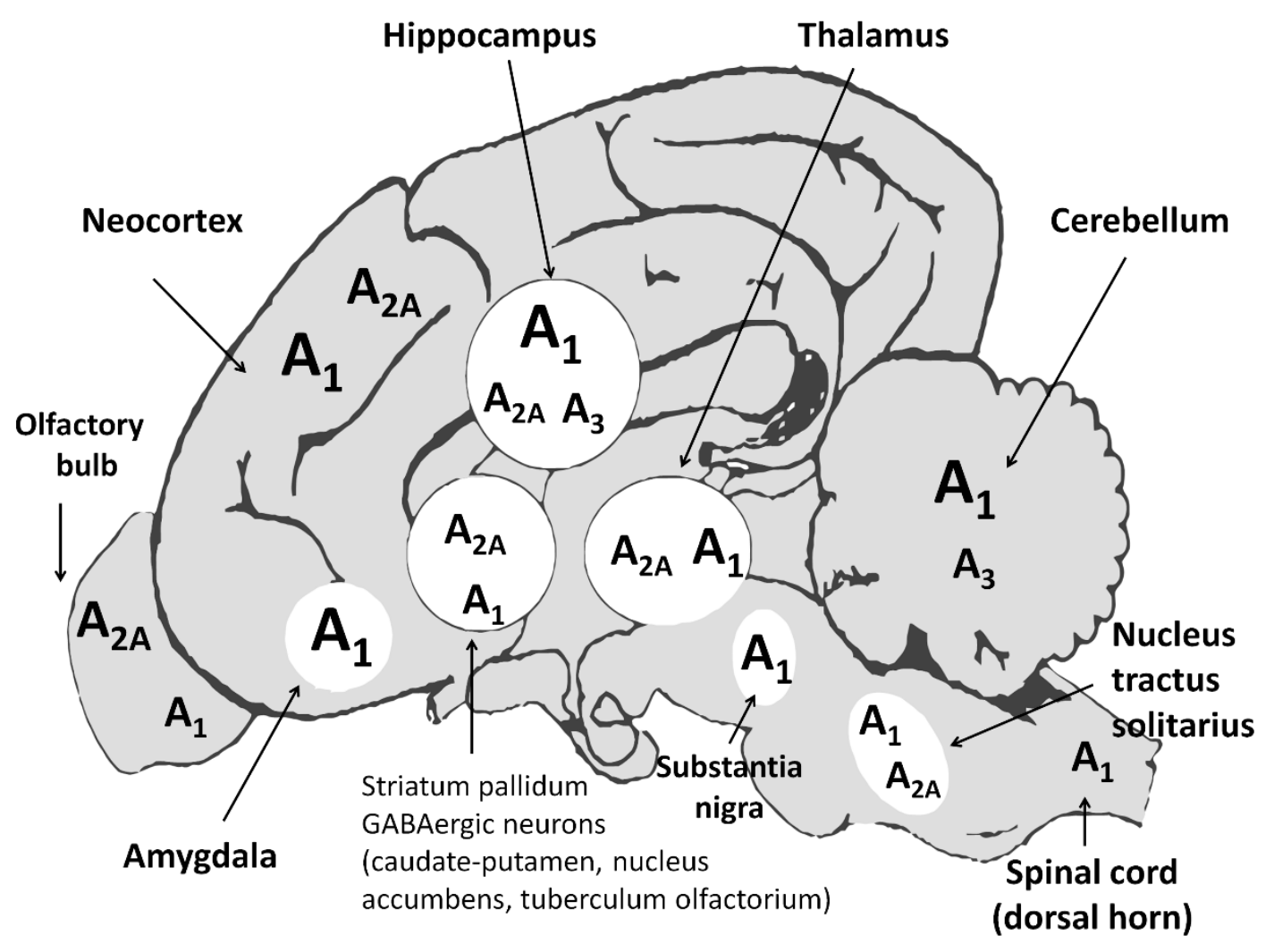

Figure 1 Anatomical distribution of adenosine receptors. Their distribution in the cerebral parenchyma is key for the physiological effects of caffeine. A1 receptors are found in high densities in the temporal cortex and hypothalamus, while A2A receptors exist in the amygdala, hippocampus, nucleus accumbens, prefrontal cortex, and striatum.

\section{Anxiogenic effect}

The increased state of alertness brought on by caffeine consumption has also been related to an anxiogenic effect manifested in higher blood pressure and heart rate, nausea, and trembling, signs similar to those seen in states of fear (Charney et al 1985). In human medicine, caffeine consumption has been related to these signs and higher cortisol levels. Antagonism of the $\mathrm{A} 1$ and $\mathrm{A} 2 \mathrm{~A}$ receptors (Fredhom et al 1999) modulates the transmission of stimuli in the glial cells and CNS neurons that are involved in anxiety behavior (Ribeiro et al 2002; Hohoff et al 2010). Evidence of this has been seen in studies with mice, where deactivation of the genes related to the A1 and A2 adenosine receptors induces greater anxiety (Ledent et al 1997; Johansson et al 2001; Smith et al 2012). Studies have established that areas like the amygdala, prefrontal medial cortex, and mid-brain have moderate densities of $\mathrm{A} 1$ and $\mathrm{A} 2 \mathrm{~A}$ receptors. All these regions perform key functions in the processing of threats, fear, and anxiety (Svenningsson et al 1997; Rosin et al 1998; Price, 2005).

Bhattacharya et al (1997) observed a similar effect in open-field and elevated plus-maze tests with rats that were administered caffeine intraperitoneally at 10,25 , and $50 \mathrm{mg}$ $\mathrm{kg}-1$. They concluded that the rats that received the $50 \mathrm{mg} \mathrm{kg}$ 1 dose reduced their entries into, and time devoted to exploring, the open arms, as well as their social interaction with congeners and alimentation in unfamiliar environments. They concluded that chronic caffeine consumption induces behavioral effects similar to those of anxiety, through antagonism of the adenosine $\mathrm{A} 1$ and $\mathrm{A} 2$ receptors.

\section{Effects on cognition}


One of the most contrasting effects of caffeine involves cognition or memory improvement, which is reflected in a greater capacity for attention and enhanced problem-solving (Assis et al 2018). Studies with humans have demonstrated that doses of $0.5-4 \mathrm{mg} \mathrm{kg}-1$ increase cognition by improving performance in problem-solving in working environments in a manner considered dose-dependent (McLellan et al 2016). Studies by Angelucci et al (2002) evaluated the effects of adenosine antagonists on learning and memory in adult Wistar rats that were given caffeine intraperitoneally 30 minutes before being trained in Morris' water maze test. In that study, administering caffeine post-training increased memory retention at doses of $0.3-10 \mathrm{mg} \mathrm{kg}-1$. Pre-training administration, in contrast, did not alter the animals' performance either during training or on the test itself; hence, it did not foster memory acquisition. These discrepancies have been observed, as well, in other studies of cognitive performance in rodents (Pan and Chen; 2007; Soellner et al 2009; Cognato et al 2010).

\section{Effect of caffeine on neurotransmitter} modulating systems

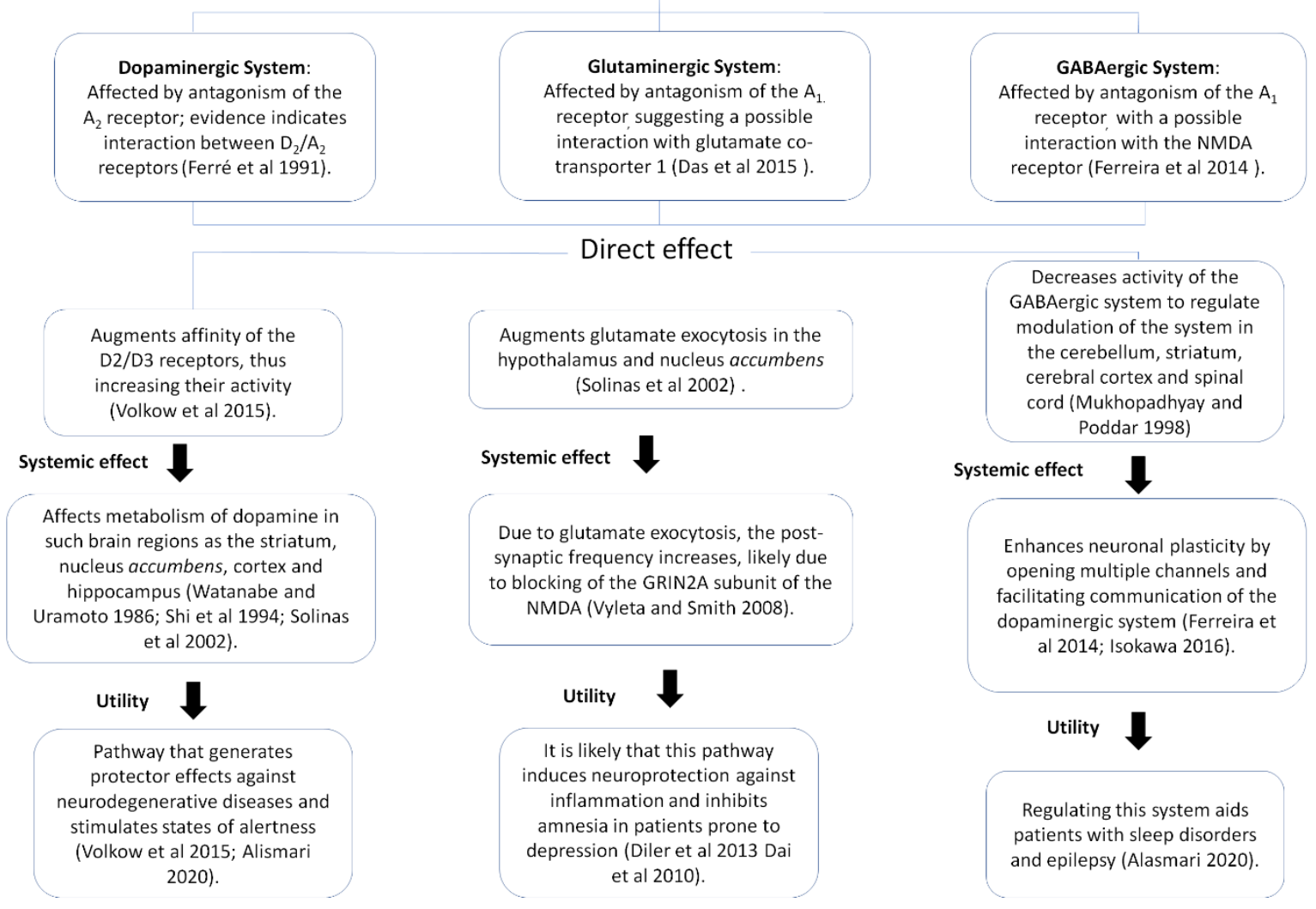

Figure 2 Effects of caffeine on the systems that modulate neurotransmitters. These depend on the disposition of the adenosine receptor and the dominance of the modulated neurotransmitter, so both factors influence the physiological effects observed in clinical medicine. N-methylD-aspartate (NMDA).

The mechanism that induces memory enhancement may be mediated by the interaction between the NMDA receptors and treatment with caffeine at low doses, which have been shown to induce memory improvement in male Wistar rats (Diler et al 2013). Recently, Kim et al (2018) refuted the hypothesis of interaction with the GRIN2A receptor -which functions as a subunit of NMDA- because they failed to detect any significant interaction $(P=0.47)$. Their findings suggest that the interaction of NMDA with caffeine consumption is not the mechanism that impedes memory dysfunction. These observations make it clear that caffeine improves cognition and memory retention, but does not induce memory acquisition, especially in older animals at low or moderate doses.

\section{Neuroprotector effect}

Neuroprotection through caffeine consumption has spurred special interest recently in both veterinary and human medicine that has led to the elaboration of numerous studies (e.g. Kalda et al 2006; Brothers et al 2010; Lopes et al 2019). The interval during which caffeine provided neuroprotection 
in a model of mice prone to Parkinson's disease that received caffeine at doses of $30 \mathrm{mg} \mathrm{kg}-1$ pre- and post-treatment with 1-methyl-4phenyl-1,2,3,6-tetrahydropyridine (which induces neuronal lesions mediated by dopamine) showed that, whether administered before or after the dopaminergic lesion, caffeine attenuated neurotoxic effects for 10 and 30 minutes and 1 and 2 hours -but not after these intervals- through a neuroprotector effect that derives from its metabolites. The neuroprotection provided by caffeine is mediated by the dopaminergic pathway when the antagonism of the A2A dopaminergic receptors occurs (Oztas et al 2002; Kalda et al 2006)

Administering a dose of caffeine to mouse offspring at 10 days of postnatal age, posterior to an ischemic hypoxic lesion, produced neuroprotection, immunomodulation, and partial functional recovery. Improvement on the open-field behavioral test reduced the loss of white and gray matter and apoptotic cell density, accompanied by a reduction of the amoeboid microglia and the astrogliosis area, and modulation of the expression of pro-inflammatory cytokines in mice treated with caffeine, compared to a control group (Di Martino et al 2020).

The neuroprotector effects observed under caffeine administration include preventing cell damage generated by cell metabolism. This protection is not limited to the neuronal level, as Barcelos et al (2014) reported that caffeine at a dose of $6 \mathrm{mg} \mathrm{kg-1}$ improved enzymatic hepatic responses in rats under conditions of high-demand exercise, suggesting that it protects cells from damage caused by oxidative stress. Lv et al (2010) reported an additional behavior of this drug in rats subjected to gradual alcohol consumption followed by treatment with various doses of caffeine (5, 10, $20 \mathrm{mg} \mathrm{kg}-1)$. They observed that caffeine attenuated elevation of the enzyme aminotransferase, the inflammatory cytokines, and hepatocyte necrosis. Caffeine generated a type of cytoprotection while also retarding inflammatory effects caused by the consumption of intoxicating agents like alcohol. This effect is associated with blocking the $\mathrm{A} 2 \mathrm{~A}$ receptors and attenuation of the inflammatory response produced by oxidative stress (Leite et al 2011). A2A receptors are abundant in the nerve endings of glutaminergic cells in the striatum, cortex, basal ganglia, and brain stem (Popoli et al 1995; Sebastiao and Ribeiro, 1996; Marchi et al 2002).

In one animal model, attenuation of glutamate exocytosis impeded neuronal excitation, as seen in electroencephalographic changes in mice exposed to caffeine (Corsi et al 2000). In other cases, low doses of caffeine adequately blocked the $\mathrm{A} 2 \mathrm{~A}$ receptor, with a possible attenuation of glutamate levels accompanied by significant electroencephalographic changes (Popoli et al 2002).

In light of these observations, caffeine may be able to prevent the changes that characterize neuroinflammation (Brothers et al 2010) due to its neuroprotector effect as a dosedependent cytoprotector. This protection is provided through both the dopaminergic and glutaminergic pathways, independently of the dose administered, but in the presence of a certain density of A2A receptors. Therefore, this receptor is in charge of the protective properties of the methylxanthines.

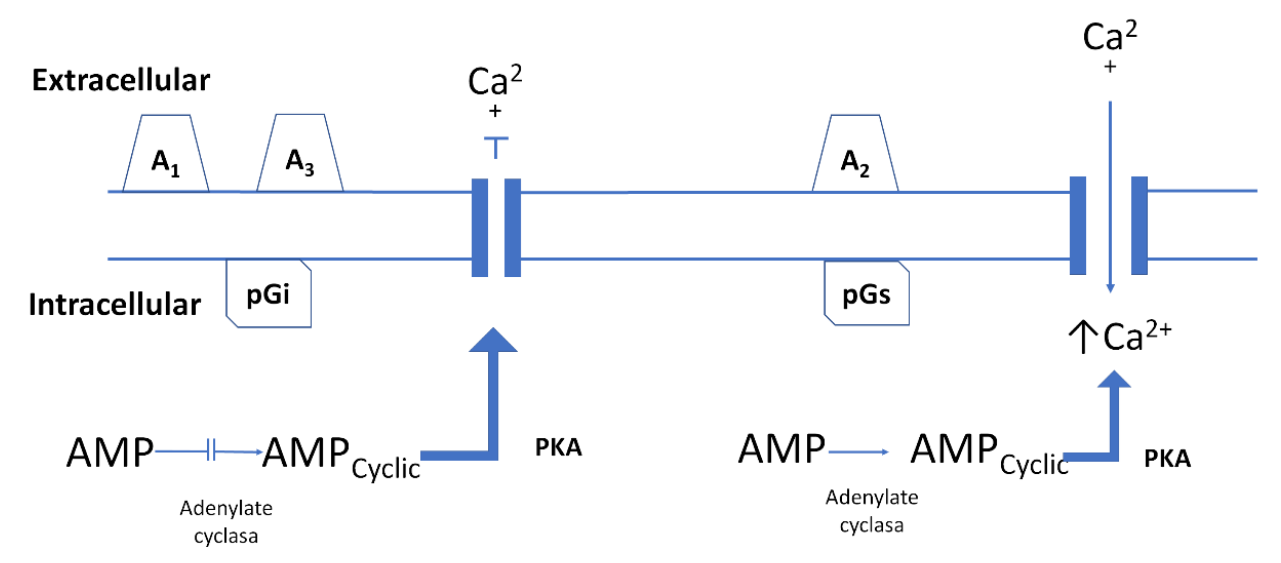

Figure 3 Representation of adenosine receptor antagonism. By antagonizing the A1 or A3 receptors linked to inhibitory (pGi), caffeine produces inhibition of adenylate cyclase activity, thus impeding the conversion of monophosphate (AMP) into cyclic AMP (AMPc). This, in turn, reduces the activity of the kinase A protein (PKA), blocking the phosphorylation of $\mathrm{Ca}^{2+}$ channels. Antagonism of A2 receptors is associated with stimulating G proteins (pGs) that produce an increase of adenylate cyclase and cyclic AMP, which increase the sensitivity of the calcium channels to facilitate entry into the cell.

\section{Effects in neurodegenerative diseases}

Retrospective studies report a negative relation between caffeine consumption and the risk of suffering neurodegenerative diseases, due to antagonism of A2A receptors (El Yacoubi et al 2001; Góngora et al 2005; Kalda et al 2006). This has been explained by the possible interaction of this receptor with memory and behavioral disorders. Caffeine may perform a neuroprotector function due to the increase in extracellular glutamate (Alasmari, 2020). Instilling caffeine at concentrations of $50 \mu \mathrm{M}$ can facilitate synaptic transmission by $40 \%$ and reduce the amplitude of long-term 
potentializing by $35 \%$, in association with phenomena of enhanced neuronal plasticity and the blocking of adenosine receptors (Lopes et al 2019).

Recently, the NMDA receptors have been related to the capacity to control the glutaminergic pathway and cerebral metabolism (Lopes et al 2019).

Another possible mechanism for impeding the development of neurodegenerative diseases entails maintaining the integrity of the blood-brain barrier through its modulation (Chen et al 2010).

Additional studies are required to establish a relation between these two phenomena and allow researchers to determine their benefits in treating neurodegenerative diseases or to replicate these effects in other species with diseases that manifest similar behaviors, such as cognitive dysfunction in canines (Dewey et al 2019).

It is evident that the use of caffeine can prevent, or retard, the signs of neurodegenerative diseases, though it is not yet clear which pathway produces the mechanism of protection against them. Hence, it is necessary to review the models used in studies of this drug in greater depth and replicate the aforementioned phenomena in other species with similar diseases.

\section{Neurotoxic effects}

Abuse in caffeine consumption can cause such health problems as a greater risk of suffering convulsions, development of arrhythmias, and a reduced hypoxic response (Ilback et al 2007; Vesoulis et al 2016; Van Koert et al 2018; Qian et al 2019). Studies of species like dogs and rats have demonstrated that caffeine increases neurotoxicity and makes organisms more prone to suffering convulsions (Basset et al 2014). This mechanism has been associated with increased glutamate exocytosis, which generates greater neuronal activity (Fredholm and Hedqvist, 1980; Hoexter et al 2005). The use of other methylxanthines -e.g. theophylline- has been associated with convulsions in rats (Yasuhara and Levy; 1988), though its neurotoxic effect depends on such factors as treatment duration, interaction with other drugs, and dosage (Van Koert et al 2018; Alasmari, 2002). The latter factor has been shown to promote neurotoxicity in the granular cells of the cerebellum of rat offspring, which is significant for the onset of convulsions (Gepdiremen et al 1988). Finally, an overdose of $50 \mathrm{mg} \mathrm{kg}-1$ induced significant neuronal death in various brain regions in rats (Kang et al 2002).

Caffeine does not affect only the neuronal structure, but can also produce alterations in the amounts of receptors derived from the antagonism of adenosine receptors, induce changes in cardiac function and growth, and even modify deoxyribonucleic acid methylation (Buscariollo et al 2014). These effects were evaluated in vitro in embryos of complete murines and isolated hearts, where it was possible to identify that caffeine reduced the normal heart rate with hypoxia, a potentially worrisome aspect that should be considered during gestation. This phenomenon occurred due to antagonism of the A1 and A2 receptors (Buscariollo et al 2011).

Although caffeine does provide potential benefits, its use and consumption can produce affectations in the long term. For this reason, it is necessary to consider subjects' physiological status, gestation, and general state of health since, as we elucidated above, this drug can present severe interactions through antagonism of the adenosine receptors.

\section{Behavior in addictions}

One of the principle problematics associated with caffeine consumption is addiction (Lee et al 2020), a situation that provokes an increase of functional brain activity due to the release of dopamine, specifically in the cortex of the nucleus accumbens, which has been identified as a key structure in reward, motivational and addictive behaviors (Griffiths and Woodson 1988; Nehlig 1999).

Studies in humans have identified that the behaviors associated with caffeine addiction include irritability, anxiety, fatigue, and altered mobility (American Psychiatric Association, 2013; Mitchell et al 2014). Concerning animals, discussions regarding the presence of these addictive behaviors are ongoing (Edwards et al 2012; Park et al 2015; Avegno and Gilpin 2019).

A recent study of male Wistar rats by Lee et al (2020) analyzed whether prolonged voluntary caffeine consumption led to compulsive ingestion. They divided the rats into three groups concerning exposure to caffeine (low, medium, high), observing compulsive consumption in the rats that received the high concentration, but not in those exposed to low or medium levels. Their study successfully identified such behaviors as irritability, anxiety, and sensitivity to pain.

According to this evidence, it may be that animals present behaviors similar to those of humans about addiction since they have cerebral structures similar to those that cause these behaviors in humans.

\section{Perspectives for the clinical use of caffeine}

Diverse clinical studies suggest potential uses of caffeine consumption or administration (Lucas et al 2011; Colella et al 2018; Franca et al 2018). Antagonism of the A1 receptors in the hippocampus (Salamone and Correa 2012) has led to the postulate that caffeine significantly reduces the risk of depression in women (Lucas et al 2011).

Caffeine may also reinforce muscular activity and enhance recognition in patients with neurocognitive deficits (Assis et al 2018). Studies with humans have corroborated improvements in performance at work or in sports (Burke, 2008; Cappelletti et al 2015). In this regard, in addition to enhancing cognition, caffeine could generate benefits for 
patients with attention deficit and hyperactivity disorders by normalizing dopamine levels (Franca et al 2018).

A final interesting aspect that is gaining importance is using caffeine to strengthen the blood-brain barrier as a means to prevent brain damage caused by acute inflammation by activating the microglia through the $\mathrm{A} 2 \mathrm{~A}$ receptors (Colella et al 2018). Clinical uses of caffeine in human medicine are supported by such experimental evidence. In animals, in contrast, it is necessary to establish up-to-date models for various species that suffer pathologies that may be comparable to those analyzed in humans to determine whether caffeine has the same therapeutic potential.

\section{Final Considerations}

This review analyzed and contrasted the neurological effects associated with the neurobehavioral and neuroprotector effects of caffeine, while also outlining potential clinical uses of this drug in animal models for events identified by antagonism of the A1, A2 and A3 adenosine receptors in the CNS and the modulation of neurotransmitters -mainly dopaminergic, glutaminergic and GABAminergicthat constitute important systems in neuronal activity. This modulation of neurotransmission systems plays a key role in neuroprotection by reducing the toxicity caused by dopamine.

Recent evidence demonstrates that by regulating these neurotransmission systems it is possible to generate protection against inflammation of the CNS, where there is sufficient evidence of caffeine's ability to restore cognition and prevent memory loss in such conditions as Parkinson's and Alzheimer's disease. However, it is important to develop new study models for other species to determine whether the behavior of this molecule is similar, intending to establish other clinical applications that take advantage of caffeine's effects on behavior and neuroprotection.

\section{Conflict of Interest}

The authors declare that they have no conflict of interest.

\section{Funding}

This research did not receive any financial support.

\section{References}

Abu- Sa'da OS, Armstrong EA, Scott O, Shaw O, Nguyen AT, Shen K, Cheung P, Baker G, Yager JY (2018) The effect of caffeine on the neuropathological and neurobehavioral outcome in the newborn rat. Journal of Caffeine and Adenosine Research 8:143-152.

Alasmari F (2020) Caffeine induces neurobehavioral effects through modulating neurotransmitters. Saudi Pharmaceutical Journal 28:445451.

American Psychiatric Association (2013) Diagnostic and Statistical Manual of Mental Disorders, 5th edition, Washinton, DC: American Psychiatric Press.
Angelucci MEM, Cesário C, Hiroi RH, Rosalen PL, Cunha D (2002) Effects of caffeine in learning and memory in rats tested in the Morris water maze. Bazilian Journal of Medical and Biological Research 35:1201-1208.

Assis MS, Soares AC, Sousa DN, Eudes- Filho J, Faro LR, Carneiro FP, Silva MV, Motoyama AB, Souza GM, Marchiori S, Lima NT, Boëchat- Barros R, Ferreira VM (2018) Effects of Caffeine on Behavioral and Cognitive Deficits in Rats. Basic \& Clinical Pharmacology \& Toxicology 123:435-442.

Avegno EM, Gilpin NW (2019) Inducing alcohol dependence in rats using chronic intermittent exposure to alcohol vapor. Bio- Protocol 9:e3222.

Barcelos RP, Souza MA, Amaral GP, Stefanello ST, Bresciani G, Fighera MR, Soares FAA, Barbosa NV (2014) Caffeine supplementation modulates oxidative stress markers in the liver of trained rats. Life Sciences 96:40-5.

Bassett L, Troncy E, Pouliot M, Paquette D, Ascah A, Authier S (2014) Telemetry video- electroencephalography (EEG) in rats, dogs and dogs and non- human primates: Methods in follow- up safety pharmacology seizure liability assessments. Journal of Pharmacological and Toxicological Methods 70:230-240.

Bhattacharya SK, Satyan KS, Chakrabarti A (1997) Anxiogenic action of caffeine: an Experimental study in rats Journal of Psychopharmacology 11:219-224.

Brothers HM, Marchalant Y, Wenk GL (2010) Caffeine attenuates lipopolysaccharide- induced neuroinflammation. Neurosciences Letters 480:97-100.

Burke LM, (2008) Caffeine and Sports Performance. Applied Physiology, Nutrition and Metabolism 33:1319-34.

Buscariollo DL, Breuer GA, Wendler CC, Rivkees SS, (2011) Caffeine acts via Al adenosine receptors to disrupt embryonic cardiac function. PLoS One 6:e28296.

Buscariollo DL, Fang X, Greenwood V, Xue, H, Rivkees SA Wendler CC (2014) Embryonic caffeine exposure acts via A1 adenosine receptors to alter adult cardiac function and DNA methylation in mice. PLoS One 9:e87547.

Cappelletti S, Daria P, Sani G, Aromatario M (2015) Caffeine: Cognitive and Physical Performance Enhancer or Psychoacyive Drug? Current Neuropharmacology 13:71-88.

Charney DS, Heninger GR, Jatlow PI (1985) Increased Anxiogenic Effects of Caffeine in Panic Disorders. Archives of General Psychiatry 42:233-243.

Chen X, Ghribi O, Geiger JD (2010) Caffeine Protects Against Disruptions of the Blood- Brain Barrier in Animals Models of Alzheimer's and Parkinson's Diseases. Journal of Alzheimer's Disease 20:S127-S141.

Cognato GP, Agostinho PM, Hockemeyer J, Müller CE, Souza DO, Cunha RA (2010) Caffeine and an adenosine A(2A) receptor antagonist prevent memory impairment and synaptotoxicity in adult rats triggered by a convulsive episode in early life, Journal of Neurochemistry 112:453-462.

Colella M, Zinni M, Pansiot J, Cassanello M, Mairesse J, Ramenghi L, Baud O (2018) Modulation of Microglial Activation by Adenosine A2a Receptor in Animal Models of Perinatal Brain Injury. Frontiers in Neurology 9:605.

Corsi C, Melani A, Bianchi L, Pedata F (2000) Striatal A2A adenosine receptor antagonism differentially modifies striatal 
glutamate outflow in vivo in young and aged rats. Neuroreport 11:2591-5.

Dai SS, Zhou HY, Li W, An JH, Li P, Yang N, Chen XY, Xiong RP, Liu P, Zhao Y, Shen HY, Zhu PF, Chen JF (2010) Local glutamate levels distaste adenosine A2A receptor regulation of neuroinflammation and traumatic brain injury. Journal of Neuroscience 30:5602-5010.

Das SC, Yamamoto BK, Hristov AM, Sari Y (2015) Ceftriaxone attenuates ethanol drinking and restores extracellular glutamate concentration through normalization of GLT-1 in nucleus accumbens of male alcohol-preferring rats. Neuropharmacology 97:67-74.

De Freitas AP, Ferreira DDP, Fernandes A, Martins RS, BorgesMartins VPP, Sthaler MF, Dos- Santos- Pereira M, Paes- de Carvalho R, Giestal- de- Araujo E, de Melo Reis RA, Kubrusly RC (2016) Caffeine Alters Glutamate- Aspartate Transposter Function and Expression in Rat Retina. Neuroscience 19:285-294

Dewey CW, Davies E, Xie H, Wakshlag JJ (2019) Canine Cognitive Dysfunction: Pathophysiology, Diagnosis, and Treatment. Veterinary Clinics of North America: Small Animal Practice 49:477499.

Di Martino E, Bocchetta E, Tsuji S, Mukai T, Harris RA, Blomgren $\mathrm{K}$, Ådén U (2020) Defining a Time Window for Neuroprotection and Glia Modulation by Caffeine After Neonatal Hypoxia-Ischaemia. Molecular Neurobiology 57:2194-2205.

Dias RB, Rombo DM, Ribeiro JA, Henley JM, Sebastiäo AM (2013) Adenosine: setting the stage for plasticity. Trends in Neurosciences 3:248-257.

Diler A, Ziya Y, Üzüm G (2013) N- methyl- D- aspartate Receptors Are involved in Caffeine- Induced Facilitation on Memory Retention of Passive Avoidance Learning in Rats, Journal of Caffeine Research 3:169-174.

Edwards S, Vendruscolo LF, Schlosburg JE, Misra KK, Wee S, Park PE, Schulteis G, Koob GF (2012) Development of mechanical hypersensitivity in rats during heroin and ethanol dependence: alleviation by $\mathrm{CRF}(1)$ receptor antagonism. Neuropharmacology 62:1142-1151.

El Yacoubi M, Ledent C, Parmentier M, Costentin J, Vaugeois JM (2000) The anxiogenic-like effect of caffeine in two experimental procedures measuring anxiety in the mouse is not shared by selective $\mathrm{A}(2 \mathrm{~A})$ adenosine receptor antagonists. Journal of Psychopharmacology 148:153-63.

Ferré S, von Euler G, Johansson B, Fredholm BB, Fuxe K (1991) Stimulation of high- affinity adenosine A2 receptors decreases the affinity of dopamine D2 receptors in rat striatal membranes. Proceedings of the National Academy of Sciences the United States of America 88:7138-7241.

Ferreira DDP, Stutz B, de Mello FG, Reis RAM, Kubrusly RCC (2014) Caffeine Potentiates the Release of GABA Meidated by NMDA Receptor Activation: Involvement of A1 Adenosine Receptors. Neuroscience 281:208-215.

Fisone G, Borgkvist A, Usiello A (2004) Caffeine as a psychomotor stimulant: mechanism of action. Cellular and Molecular Life Sciences 61:857-72.

Franca AP, Takahashi RN, Cunha RA, Prediger RD (2018) Promises of Caffeine in Attention- Deficit/ Hyperactivity Disorder: From Animal Models to Clinical Practice. Journal of Caffeine and Adenosine Research 8:131-142.

Fredholm BB, AP IJ, Jacobson KA, Linden J, Muller CE (2011) International Union of Basic and Clinical Pharmacology. LXXXI
Nomenclature and classification of adenosine receptors--an update. Pharmacological Reviews 63:1-34.

Fredholm BB, Bättig K, Holmén J, Nehlig A, Zvartau EE (1999) Actions of caffeine in the brain with special reference to factors that contribute to its widespread use. Pharmacological Reviews 51:83133.

Fredholm BB, Chen JF, Cunha RA, Svenningsson P, Vaugeosis JM (2005) Adenosine and brain function. International Review of Neurobiology 63:191-270.

Fredholm BB, Hedqvist P (1980) Modulation of neurotransmission by purine nucleotides and nucleosides. Biochemical Pharmacology 29:1635-1645.

Ganio MS, Klau JF, Casa DJ, Armstrong LE, Maresh CM (2009) Effect of caffeine on sport- specific endurance perfonmance: a systematic review The Journal of Strength and Conditioning Research 23:315-24.

Garrett BE, Holtzman SG (1994) D1 and D2 dopamine receptorantagonists block caffeine- induced stimulation of locomotor activity in rats. Pharmacology Biochemistry and Behavior 47:89-94.

Gepdiremen A, Sönmez S, Ikbal M, Düzenli S, Tuna S (1998) Response to nimodipine in caffeine- induced neurotoxicity in cerebellar granular cell culture of rat pups. Pharmacological Research 38:239-242.

Góngora-Alfaro JL, Moo-Puc RE, Villanueva TJ, ArankowskySandoval G, Álvarez-Cervera FJ, Pineda-Cortés JC, Heredia-López FJ, Bata-García JL (2005) La cafeína y los antagonistas de los receptors A2A de la adenosina como posibles adyuvantes de la terapia anticolinérgica en la enfermedad del Parkinson. Revista Biomedica 16:99-111.

Griffiths RR, Wooddsom PP (1988) Caffeine physical dependence: a review of human and laboratory animal studies. Journal of Psychopharmacology 94:437-451.

Halldner L, Adén U, Dahlberg V, Johansson B, Ledent C, Fredholm BB (2004) The Adenosine A1 receptor contributes to the stimulatory, but not the inhibitory effect of caffeine on locomotion: a study in mice lacking adenosine A1 and/ or A2A receptors. Neuropharmacology 46:1008-1017.

Hoexter MQ, Rosa PS, Tufik S, Mello LE (2005) Consequences of Prolonged Caffeine Administration and Its Withdrawal on Pilocarpine- and Kainate- induced Seizures in Rats. Epilepsia 46:1401-1406.

Hohoff C, Mullings EL, Heatherley SV, Freltag CM, Neumann LC, Domschke K, Krakowitzky P, Rothermundt M, Keck ME, Erthardt A, Unschuld PG, Jacob C, Fritze J, Bandelow B, Maler W, Holsboer F, Rogers PJ, Deckert J (2010) Adenosine A(2A) receptor gene: evidence for association of risk variants with panic disorder and anxious personality. Journal of Psychiatic Research 44:930-937.

Hughes RN, (2016) Neurobehavioral Aspects of Caffeine In: Preedy VR (ed) Neuropathology of Drug Addictions and Substance Misuse, Volume 3: General Processes and Mechanisms, Prescription Medications, Caffeine and Areca, Polydrug Misuse, Emerging Addictions and Non- Drug Addictions, (Academis Press), pp 775784 .

Ilback NG, Siller M, Stalhandske T (2007) Evaluation of cardiovascular effects of caffeine using telemetric monitoring in the conscious rat. Food and Chemical Toxicology 45:834-842.

Isokawa M (2016) Caffeine-induced suppression of GABAergic inhibition and calcium-independent metaplasticity. Neural Plasticity doi:http://dx.doi.org/10.1155/2016/1239629. 
Johansson B, Halldner L, Dunwiddie TV, Masino SA, Poelchen W, Giménez- Llort L, Escorihuela RM, Fernández- Teruel A, Wiesenfeld- Hallin Z, Xu XJ, Hardemark A, Betsholtz C, Herlenius, E, Fredholm BB (2001) Hyperalgesia, Anxiety, and Dercreased Hypoxic Neuroprotection in Mice Lacking the Adenosine A1 Receptor. Proceedings of the National Academy of Sciences of the United States of America 98:9407-9412.

John J, Kodama T, Siegel JM (2014) Caffeine promotes glutamate and histamine release in the posterior hypothalamus. American Journal of Physiology- Regulatory Integrative and Comparative Physiology 307:R704- R710.

Kalda A, Yu L, Oztas E, Chen JF (2006) Novel Neuroprotection by Caffeine and Adenosine A(2A) Receptor Antagonists in Animal Models of Parkinson's Diseases. Journal of the Neurological Science 248:9-15.

Kamp TJ, Hell JW (2000) Regulation of cardiac L- type calcium channels by protein kinase A and protein kinase C. Circulation Research 87:1095-1102.

Kang SH, Lee YA, Won SJ, Rhee KH, Gwag BJ (2002) Caffeineinduced Neuronal Death in Neonatal Rat Brain and Cortical Cell Cultures. Neuroreport 13:1945-1950.

Kerkhofs A, Xavier AC, da Silva BS, Cans PM, Sander I, Johannes CB, Samira GF, Rodrigo AC, Huibert DM (2017) Caffeine Controls Glutamatergic Synaptic Transmission and Pyramidal Neuron Excitability in Human Neocortex. Frontiers in Pharmacology 8:899.

Kim IY, O'Reilly EJ, Hughes KC, Gao X, Schwarzschild MA, McCullough ML, Hannan MT, Betensky RA, Ascherio A (2018) Interaction Between Caffeine and Polymorphisms of Glutamate Inotropic Receptor NMDA Type Subunit 2A (GRIN2A) and Cytochrome P450 1A2 (CYP1A2) on Parkinson's Disease Risk. Movement Disorders 33:414-420.

Kolahdouzan M, Hamadeh MJ (2016) The neuroprotective effects of caffeine in neurodegenerative diseases. CNS Neuroscience \& Therapeutics 23:272-290.

Ledent C, Vaugeois JM, Schiffmann SN, Pedrazzini T, El Yacoubi M, Vanderhaeghen JJ, Costentin J, Heath JK, Vassart G, Parmentier M (1997) Aggressiveness, hypoalgesia and high blood pressure in mice lacking the adenosine A2A receptor. Nature 388:674-678.

Lee CH, George O, Kimbrough A (2020) Chronic voluntary caffeine intake in male Wistar rats reveals individual differences in addictionlike behavior. Pharmacology, Biochemistry and Behavior 191:172880.

Leite MR, Wilhelm EA, Jesse CR, Brandäo R, Nogueira CW (2011) Protective effect of caffeine and a selective A2A receptor antagonist on impairment of memory and oxidative stress of aged rats. Experimental Gerontology 46:309-15.

Lopes JP, Pliássova A, Cunha RA (2019) The physiological effects of caffeine on synaptic transmission and plasticity in the mouse hippocampus selectively depend on adenosine A1 and A2A receptors. Biochemical Pharmacology 166:313-321.

Lucas M, Mirzaei F, Pan A, Okereke OI, Willett W, O'Reilly EJ, Koenen K, Ascherio A (2011) Coffee, Caffeine, and risk of depression among women. Archives of Internal Medicine 171:15711578.

Lv X, Chen Z, Li J, Zhang L, Liu H, Huang C, Zhu P (2010) Caffeine protects against alcoholic liver injury by attenuating inflammatory response and oxidative stress. Inflammation Research 59:635-645.

Marchi M, Raiteri L, Risso F, Vallarino A, Bonfanti A, Monopoli A, Ongini E, Raiteri M (2002) Effect of adenosine A1 and A2A receptor activation on the evoked release of glutamate from rat cerebrocortical synaptosomes. British Journal of Pharmacology 136:434-440.

Marin MT, Zancheta R, Paro AH, Possi APM, Cruz FC, Planeta CS (2011) Comparison of caffeine- induced locomotor activity between adolecent and adult rats. European Journal of Pharmacology 660:363-367.

Mc Lellan TM, Caldwell JA, Lieberman HR (2016) A Review of caffeine's effects on cognitive, physical and occupational performance. Neuroscience \& Biobehavioral Reviews 71:294-312.

Mitchell DC, Knight CA, Hockenberry J, Teplansky R, Hartman TJ (2014) Beverage caffeine intakes in the U.S. Food and Chemical Toxicology 63:136-142.

Mukhopadhyay S, Poddar MK (1998) Is GABA involved in the development of caffeine tolerance? Neurochemical Research 23:6368.

Nehlig A (1999) Are we dependent upon coffee and caffeine? A review on human and animal data. Neuroscience \& Biobehavioral Reviews 23:563-576.

Ohta A, Sitkovsky M (2001) Role of G-protein-coupled adenosine receptors in downregulation of inflammation and protection from tissue damage. Nature 414:916-920.

Oztas E, Kalda A, Xu K, Irrizary MC, Schwarzchild MA, Chen JF (2002) Caffeine attenuates MPTP- induced loss dopaminergic neurons in substantia nigra in mice. Society for Neuroscience A487.6.

Pan HZ, Chen HH (2007) Hyperalgesia, low- anxiety, and impairment of avoidance learning in neonatal caffeine- treated rats. Psychopharmacology (Berl) 191:119-125.

Park PE, Schlosburg JE, Vendruscolo LF, Schulteis G, Edwards S, Koob GF (2015) Chronic CRF1 receptor blockade reduces heroin intake escalation and dependence-induced hyperalgesia. Addiction Biology 20:275-284.

Popoli P, Betto P, Reggio R, Ricciarello G (1995) Adenosine A2A receptor stimulation enhances striatal extracellular glutamate levels in rats. European Journal of Pharmacology 287:215-7.

Popoli P, Pintor A, Domenici MR (2002) Blockade of striatal adenosine A2A receptor reduces, through a presynaptic mechanism, quinolinic acid- induced excitotoxicity: possible relevance to neuroprotective interventions in neurodegenerative diseases of the striatum. Journal of Neuroscience 22:1967-1975.

Price JL (2005) Free will versus survival: brain systems that underlie intrinsic constraints on behavior. The Journal of Comparative Neurology 493:132-139.

Qian J, Chen Q, Ward SM, Duan E, Zhang Y (2019) Impacts of Caffeine during Pregnancy. Trends in Endocrinology \& Metabolism 31:218-227.

Ribeiro JA, Sebastiäo AM, de Mendonca A (2002) Adenosine receptors in the nervous system: pathophysiological implications. Progress in Neurobiology 68:377-392.

Rosin DL, Robeva A, Woodard RL, Guyenet PG, Linden J (1998) Immunohistochemical localization of adenosine A2A receptors in the rat central nervous system. The Journal of Comparative Neurology 401:163-86.

Salamone JD, Correa M (2012) The mysterious motivational functions of mesolimbic dopamine. Neuron 76:470-485. 
Sebastiao AM, Ribeiro JA (1996) Adenosine A2 receptor- mediated excitatory actions on the nervous system. Progress in Neurobiology 48:167-189.

Sheth S, Brito R, Mukherjea D, Rybak LP, Ramkumar V (2014) Adenosine receptors: expression, function and regulation. International Journal of Molecular Sciences 15:20242052.

Shi D, Nikodijevic' O, Jacobson KA, Daly JW (1994) Effects of chronic caffeine on adenosine, dopamine and acetylcholine systems in mice. Archives Internationales de Pharmacodynamie et de Therapie 328:261.

Simoes AP, Machado NJ, Goncalves N, Kaster MP, Simoes AT, Nunes A, Pereira de Almeida L, Goosens KA, Rial D, Cunha RA (2016) Adenosine A2A receptors in the amygdala control synaptic plasticity and contextual fear memory. Neuropsychopharmacology 41:2862-2871.

Smith JE, Lawrence AD, Diukova A, Wise RG, Rogers PJ (2012) Strom in a coffe cup: caffeine modifies brain activation to social signals of treat. Social Cognitive and Affective Neuroscience 7:831840 .

Soellner DE, Grandys T, Nuñez JL (2009) Chronic prenatal caffeine exposure impairs novel object recognition and radial arm maze behaviors in adult rats. Behavioral Brain Research 205:191-199.

Sökmen B, Armstrong LE, Kraemer WJ, Casa DJ, Dias JC, Judelson DA, Maresh CM, (2008) Caffeine use in sports: cosniderations for the athlete. The Journal of Strength and Conditioning Research 22:978-986.

Solinas M, Ferre S, Zhi-Bing Y, Karcz-Kubicha M, Popoli P, Steven RG (2002) Caffeine induces dopamine and glutamate release in the shell of the nucleus accumbens, Journal of Neurosciences 22:63216324.

Southward K, Rutherfurd- Markwick K, Ali A (2018) The Effect of Acute Caffeine Ingestion on Endurance Performance: A Systematic Review and Meta- Analysis. Sport Medicine 48:1913-1928.

Spaeth AM, Goel N, Dinges D (2014). The Cumulative Neurobehavioral and Physiological Effects of Chronic Caffeine Intake: Individual Differences and Implications for the Use of Caffeinated Energy Products Nutrition Reviews 72:34-47.

Svenningsson P, Hall H, Sedvall G, Fredholm BB (1997) Distribution of adenosine receptors in the postmortem human brain: an extended autoradiographic study. Synapse 27:322-335.
Van Koert RR, Bauer PR, Schuitema I, Sander JW, Visser GH (2018) Caffeine and seizures: A systematic review and quantitative analysis. Epilepsy \& Behavior 80:37-47.

Vesoulis ZA, McPherson C, Neil JJ, Mathur AM, Inder TE (2016) Early High- Dose Caffeine Increases Seizure Burden in Extremely Preterm Neonates: A Preliminary Study. Journal of Caffeine Research 6:101-107.

Villanueva-García D (2007) Acute lung diseases. En: Ballesteros del Olmo JC, Villanueva-García D, Castro MJ, Cruz Castelazo MC, Delgadillo Avendaño JM, Estrada Flores JV. PAC Pediatría-V. Libro 11. Enfermedades pulmonares en el recién nacido. México: Intersistemas; pp. 690-695.

Villanueva-García D (2011) Pulmonary Arterial Hypertension. En: Murguía T, Villanueva D, Lara G, editors. Neonatología, esencia, arte y praxis. Mc Graw Hill, Mexico City, Mexico, pp. 88-94.

Villanueva-García D, Ibarra RD (2016) Chapter: Bronchopulmonary dysplasia. Programa de Actualización Continua en Neonatología, PAC®. Federación Nacional de Neonatología de México AC. En: Mancilla and Villanueva-García editors. Editado por Intersistemas S.A. de CV. Neonatologia-4/Libro 2/Insuficiencia Respiratoria Neonatal, Ciudad de México, pp. 40-58.

Villegas SR, Villanueva-García D (2016) Transient tachypnea of the newborn. Programa de Actualización Continua en Neonatología, PAC®. Federación Nacional de Neonatología de México AC. En: Mancilla and Villanueva-García editors. Editado por Intersistemas S.A. de CV. Neonatologia-4/Libro 2/Insuficiencia Respiratoria Neonatal, Ciudad de México, pp. 40-58.

Volkow ND, Wang GJ, Logan J, Alexoff D, Fowler JS, Thanos PK, Wong C, Casado V, Ferre S, Tomasi D (2015) Caffeine increases striatal dopamine D2/ D3 receptor availability in the human brain. Translational Psychiatry 5:e549.

Watanabe H, Uramoto H (1986) Caffeine mimics dopamine receptor agonists without stimulation of dopamine receptors. Neuropharmacology 25:577-581.

Yasuhara M, Levy G (1988) Caffeine as a potential risk factor for theophylline neurotoxicitym. Journal of Pharmaceutical Sciences 77:745-747.

Zheng X, Hasegawa H (2016) Administration of Caffeine Inhibited Adenosine Receptor Agonist- Induced Decreases in Motor Performance, Thermoregulation, and Brain Neurotransmitter Release in Exercising Rats. Pharmacology, Biochemistry and Behavior 140:82-89. 